\title{
A atribuição de responsabilidade civil ao Estado em estabelecimentos prisionais geridos através de cogestão e parcerias público-privadas: um estudo aplicado ao paradigmático evento ocorrido no complexo penitenciário Anísio Jobim
}

The attribution of civil responsibility to the state at some prison establishments managed through partnerships between public and private sectors: a study applied to the emblematic case occurred at the Anisio Jobim's prison

Marco Antonio Rocha Ferreira Faculdade Milton Campos, FMC, Brasil

Hamilton da Costa Mitre de Andrade Pontifícia Universidade Católica de Minas Gerais, PUC Minas, Brasil

Resumo O presente artigo busca fazer um estudo sobre a responsabilidade civil do Estado por fatos ocorridos em estabelecimentos prisionais, notadamente quando esses são geridos em parceria com o setor privado, identificando no direito pátrio os fundamentos capazes de dirimir conflitos de atribuição. A concessão de tal atividade tem se tornado prática comum no Brasil e, em virtude de problemas peculiares ao nosso sistema carcerário, como a superlotação e o envolvimento dos detentos com facções criminosas, conflitos como o enfrentado pelo 
Complexo Penitenciário Anísio Jobim serão cada vez mais frequentes. Urge, nesses casos, estabelecer regras claras de repartição da responsabilidade entre as partes contratantes, de forma a não onerar o erário com indenizações indevidas, nem desestimular a participação do particular no empreendimento.

Palavras-chave: Responsabilidade Civil do Estado. Estabelecimentos Prisionais. Cogestão. Parceria Público Privada.

Abstract The present article seeks to run a study about the civil state's responsibility for the facts occurred in prison, especially when they are managed by private companies, identifying the fundamental in the right capable of settling conflicts. This kind of partnership is becoming common in Brazil. Mainly because of some peculiar issues in our prison system, such as overcrowded prisons and rivalry among inmate gangs. Conflicts as faced for the Anísio Jobim's Prison will happen even more frequently. On those cases, it is necessary to establish clear rules to split responsibility between contractors, without becoming a burden to the government or discouraging the private sector to get into the business. Key-words: Civil State’s Responsibility. Prison. Double Managed. Partnerships Between Public and Private Sectors.

\section{INTRODUÇÃO}

No primeiro dia do ano de 2017, o Brasil assistiu atônito à rebelião ocorrida no Complexo Penitenciário Anísio Jobim, situado a poucos quilômetros de Manaus (AM). O conflito perdurou por 17 horas, computando ao seu término o saldo de 56 detentos mortos, número inferior apenas ao massacre do presídio do Carandiru (SP), datado de 2 de outubro de 1992, com o registro de 111 óbitos.

A gravidade do fato gerou grande repercussão na imprensa, que apontou a guerra entre facções como a causadora do motim. Contudo, findo o apelo midiático da rebelião, outro assunto correlato começou a ocupar as redes sociais. O governador do Amazonas, em caráter de 
urgência, determinou o início dos trâmites legais destinados a conceder indenização às famílias das vítimas da chacina. ${ }^{1}$

A mencionada ordem, embora estivesse supostamente amparada em decisão recente da Suprema Corte e na própria Constituição Federal, trouxe indignação a várias pessoas que, levando em conta a personalidade das vítimas, a causa das mortes e a inversão de prioridade no destino de recursos financeiros, defendem a não reparação dos danos causados aos parentes dos presos mortos.

Embora os motivos esboçados por esses encontrem amparo sob um ponto de vista argumentativo, é certo que não estão respaldados em qualquer norma vigente, tampouco encontram sustentação na doutrina moderna. Ainda assim persiste a pergunta: Seria possível embasar juridicamente, ante as peculiaridades do caso em tela, o não ressarcimento dos danos causados pelas mortes dos detentos?

É sabido que o estabelecimento prisional onde os presos se encontravam é fruto de uma cogestão, o que torna clara a participação de capital privado no empreendimento. Ademais, como já dito, os homicídios tiveram origem em uma guerra de facções, não sendo fruto de uma ação desastrosa do Estado, como ocorreu no Carandiru, onde policiais foram os grandes causadores das mortes.

O cabimento de indenização pelo Estado por comportamento comissivo ou omissivo que cause dano a terceiro é matéria pacífica na doutrina e jurisprudência; mas tal tema, apesar de amplamente debatido no meio jurídico, ainda suscita dúvidas ante a diversidade de situações nas quais o cidadão pode se envolver quando se relaciona com o Poder Público.

Existe ainda uma participação cada vez mais corriqueira do setor privado em empreendimentos públicos, o que incrementa a discussão sobre o tema.

Assim, para uma resposta segura à indagação citada, faz-se necessário um profundo estudo sobre a Responsabilidade Civil Extracontra-

Entre os inúmeros sites que veicularam a matéria cita-se como exemplo: https:// noticias.uol.com.br/cotidiano/ultimas-noticias/2017/01/09/uol-confere-gestao-privada-de-presidio-nao-tira-responsabilidade-do-governo-do-am.htm 
tual do Estado, analisando sua evolução no direito pátrio, as formas de sua aplicação, os casos em que a mesma é cabível e as condições de sua aplicabilidade. O presente trabalho tem por objeto, apoiado na curiosidade que o referido caso desperta, realizar a investigação completa do mencionado instituto, esclarecendo pontos obscuros e auxiliando seus leitores na análise de eventos análogos ou não.

Buscando fazer uma interlocução entre a responsabilidade estatal no Direito Administrativo, foco primeiro do trabalho, e a rebelião no presídio amazonense que servirá como baliza para ilustrar o artigo, se dividirá o trabalho em tópicos relacionados àquela matéria, sendo que ao final de cada uma será esclarecida sua pertinência com o caso em tela.

\section{Conceito de Responsabilidade CIVIL EXTRACONTRATUAL Do Estado}

Na precisa lição de Celso Antônio Bandeira de Mello, responsabilidade patrimonial extracontratual do Estado é "a obrigação que lhe incumbe de reparar economicamente os danos lesivos à esfera juridicamente garantida de outrem e que lhe sejam imputáveis em decorrência de comportamentos unilaterais, lícitos ou ilícitos, comissivos ou omissivos, materiais ou jurídicos" (MELLO, 2015, p. 1.021).

A respeito do citado conceito, é necessário fazer algumas observações a fim de delimitá-lo perante outros tipos de responsabilidade existentes no ordenamento jurídico.

Ao se mencionar a responsabilidade do Estado, é comum ter-se em mente apenas os atos do Executivo que causem danos a terceiros. Embora seja no referido poder que se encontra o maior número de comportamentos capazes de gerar responsabilização, os poderes Legislativo e Judiciário também poderão incorrer nesta quando praticam atos administrativos capazes de lesar o particular.

Da mesma forma, é necessário esclarecer que, equivocadamente, alguns costumam referir-se à responsabilidade do Estado como sendo da Administração Pública; a última não possui personalidade jurídica e, portanto, não pode ser titular de direitos e obrigações. Assim, a termino- 
A ATRIBUIÇÃO DE RESPONSABILIDADE CIVIL AO ESTADO EM ESTABELECIMENTOS PRISIONAIS GERIDOS ATRAVÉS DE COGESTÃO E PARCERIAS PÚBLICO-PRIVADAS: UM ESTUDO APLICADO AO PARADIGMÁTICO EVENTO

logia aqui utilizada será a que intitula o presente trabalho, considerada a mais apropriada.

O acréscimo do vocábulo "extracontratual" tem por objetivo distinguir essa espécie de responsabilidade da oriunda dos contratos administrativos, a qual é regida por princípios próprios.

As hipóteses de responsabilidade patrimonial do Estado são extremamente abrangentes, podendo decorrer de atos lícitos ou ilícitos, omissivos ou comissivos, materiais ou jurídicos, desde que imputáveis aos agentes públicos.

No caso paradigma deste estudo, a responsabilização do Poder Público foi embasada na omissão do Estado, parceiro no empreendimento prisional, que não proporcionou a estrutura e a vigilância adequada aos seus custodiados de modo a evitar o conflito (ato material).

\section{A eVoluÇão da responsabilidade do Estado}

O tema da responsabilidade civil do Estado tem variado no tempo e no espaço, evoluindo da total irresponsabilidade deste até o extremo oposto com a criação de uma responsabilidade objetiva.

Em razão da falta de uniformidade dos regimes jurídicos adotados pelos Estados na prestação de seus serviços e no uso de seus bens, foram desenvolvidas diversas teorias, com o objetivo de abranger as variadas situações capazes de gerar sua responsabilização.

Em alguns sistemas, como no caso do anglo-saxão, prevalecem os princípios de direito privado; já em outros regimes, como no caso do europeu-continental, são adotados o regime publicístico. O último foi o que mais influenciou o direito brasileiro neste tema.

A Teoria da Irresponsabilidade baseava-se na ideia de soberania, sendo adotada na época dos Estados absolutos. Partia-se da premissa de que, como exerce a tutela do direito, o Estado não poderia agir contra ele. Dessa assertiva extraíram-se três princípios que se tornaram a maior expressão do pensamento político vigente à época: 1) "O rei não erra" (the King can do no wrong): advindo da Inglaterra, esse princípio definia o monarca como representante de Deus na terra e, portanto, não 
submetido a qualquer processo jurisdicional ou constrangível à prática de algum ato. 2) "O que agradou ao príncipe tem força de lei" (quod principi placuit habet legis vigorem): de origem romana, onde a lei republicana determinava que o direito de um terminava onde se iniciava o do outro. Contudo, o poder do imperador estava acima da própria legislação. 3) “o Estado sou eu” (l'État c'est moi): inspirado na frase afirmada pelo rei da França Luís XIV (1661 a 1715), representante de um sistema político forte, pessoal e sem leis restritivas. Período esse denominado pelos historiadores de Absolutismo.

Obviamente, tal teoria não poderia prosperar no direito moderno. Justamente por tutelar o direito, o Estado, pessoa jurídica titular de direitos e obrigações, não pode deixar de responder quando, por sua ação ou omissão, causar danos a terceiros.

No início do século XIX, passou-se a admitir a responsabilidade do Estado ancorada em princípios do Direito Civil, razão pela qual tal se denomina tal vertente de teoria civilista da culpa.

Num primeiro momento, os atos administrativos foram classificados para fins de responsabilização em atos de império e atos de gestão. Nos primeiros, a Administração Pública atua regida por um direito especial, usando de sua supremacia sobre o administrado ou servidor e lhes impondo obrigatório atendimento. Nos segundos, a administração pratica ato sem utilizar as prerrogativas de poder público, nivelando-se nesse caso o administrado para sua consecução e se valendo do direto comum. Apenas nos atos de gestão, o Estado poderia ser responsabilizado.

A divisão mencionada causou não só dúvidas, mas também bastante confusão entre os juristas daquela época ao tentar distinguir um ato do outro. Além disso, cabia à vítima o ônus probante, uma vez que a responsabilidade era ancorada na culpa do Estado.

Tais óbices impediram a franca aplicação dessa teoria e o Estado continuou sem responder por seus atos.

Foi no direito francês que a ideia de aproximação com o conceito de responsabilidade do direito civil começou a ser paulatinamente abandonada. Defendia-se cada vez mais a necessidade de se criar um instituto próprio, apoiado nas normas e princípios de direito público. 
Com o emblemático caso Blanco, ocorrido em 1873, na cidade de Bordeaux, onde uma garota teve a perna amputada em virtude de um acidente provocado por uma vagonete pertencente a uma empresa estatal, tem início o processo de separação entre direito público e o privado, sendo que, a responsabilidade civil do Estado passa a se distanciar das normas estabelecidas pelo direito civil. Surgindo assim as teorias publicistas da responsabilidade do Estado, entre as quais destacamos: a teoria da culpa do serviço ou culpa administrativa e a teoria do risco.

A teoria da culpa administrativa procura desvincular a responsabilidade do Estado daquela atribuída ao seu funcionário quando agisse culposamente. A responsabilização do Poder Público só poderia ocorrer caso não fosse possível identificar o funcionário causador do dano, configurando assim a "culpa anônima do serviço público" caracterizada pela sua falta, mau ou intempestivo funcionamento.

Nesse sentido, José dos Santos Carvalho Filho:

A falta do serviço podia consumar-se de três maneiras: a inexistência do serviço, o mau funcionamento do serviço ou o retardamento do serviço. Em qualquer dessas formas, a falta do serviço implicava em reconhecimento da existência de culpa, ainda que atribuída ao serviço da Administração. Por esse motivo, para que o lesado pudesse exercer seu direito à reparação dos prejuízos, era necessário que comprovasse que o fato danoso se originava do mau funcionamento do serviço e que, em consequência, teria o Estado atuado culposamente. Cabia-lhe, ainda, o ônus de provar o elemento culpa (FILHO, 2015, p. 574).

Concomitantemente a essa teoria, o Conselho de Estado Francês passou a adotar também a teoria do risco que se baseia no princípio da igualdade de todos perante os encargos sociais. Assim, como as benesses da atuação estatal são usufruídas por todos, também os prejuízos sofridos por algum dos membros da sociedade deve ser dividido pelos demais. 
Aqui a culpa é substituída pelo nexo de causalidade existente entre o serviço público prestado e o dano advindo desse ao administrado. Não há necessidade de se comprovar seu mau funcionamento. Eis o cerne da responsabilidade objetiva do Estado.

A teoria da responsabilidade objetiva ou teoria do risco foi adotada pelos dois últimos Códigos Civis Brasileiros.

Parte da doutrina ainda divide a referida teoria em duas modalidades, a citar: a do risco administrativo, onde se admite as causas excludentes de responsabilidade, e a do risco integral que não permite a alegação dessas, sendo aplicada em alguns casos pontuais no direito pátrio como nos danos causados por acidentes nucleares (art. 21, XXIII, $d$, da Constituição Federal).

\subsection{A Responsabilidade no Direito Brasileiro}

Não obstante a responsabilidade civil do Estado já estivesse presente na legislação brasileira, coube ao Código Civil de 1916 delinear o instituto em seu artigo 15, o qual se mostra pertinente transcrever:

Artigo 15. As pessoas jurídicas de direito público são civilmente responsáveis por atos de seus representantes que nessa qualidade causem danos a terceiros, procedendo de modo contrário ao direito ou faltando a dever prescrito por lei, salvo o direito regressivo contra os causadores do dano (BRASIL, 1916).

O novo Código Civil manteve basicamente a mesma redação do anterior, conforme se pode observar:

Artigo 43. As pessoas jurídicas de direito público interno são civilmente responsáveis por atos dos seus agentes que nessa qualidade causem danos a terceiros, ressalvado o direito regressivo contra os causadores do dano, se houver, por partes deles, culpa ou dolo (BRASIL, 2002). 
No âmbito constitucional, a Carta Magna de 1891 previa apenas a responsabilização do funcionário público.

Somente com a promulgação da Constituição de 1934 surge a possibilidade de responsabilizar solidariamente o Estado pelos atos de seus funcionários, ocupando ambos o lugar de litisconsorte nas ações movidas contra a Fazenda Pública.

As Constituições de 1946, 1967 e 1969 definem a responsabilidade nos moldes do artigo 15 do então vigente Código Civil de 1916, cujo conteúdo foi pouco modificado pelo artigo 43 conforme disposto alhures.

Finalmente, a Constituição Federal de 1988 dispõe sobre a responsabilidade civil do Estado no seu artigo 37, $\S 6^{\circ}$., com a seguinte redação:

Artigo 37, $\S 6^{\circ}$. As pessoas jurídicas de direito público e as de direito privado prestadoras de serviços públicos responderão pelos danos que seus agentes, nessa qualidade, causarem a terceiros, assegurando o direito de regresso contra o responsável nos casos de dolo ou culpa (BRASIL, 1988).

Percebe-se que, no mencionado novel, o alcance da responsabilidade do Estado foi ampliado às pessoas jurídicas de direito privado prestadoras de serviço público, o que passou a possibilitar a responsabilização das empresas públicas, sociedades de economia mista, permissionárias e concessionárias desses serviços.

Assim preleciona Fernanda Marinela:

Quanto às pessoas jurídicas de direito privado, o texto estabelece a condição de serem prestadoras de serviços públicos. Portanto, não podem ser incluídas quaisquer pessoas da Administração Indireta, nem qualquer particular. Assim, estão sujeitas aos rigores da teoria objetiva as empresas públicas e sociedades de economia mista, desde que criadas para o serviço público, ficando aqui excluídas as exploradoras da atividade econômica. Também se submetem a esse regime os particulares prestadores de serviços públicos em razão de descentra- 
lização, como é o caso das concessionárias e permissionárias de serviços (MARINELA, 2016, p. 1.161).

É justamente como modalidade específica da última forma de contrato com o Poder Público que estão inseridos os modelos de cogestão e de parceria público-privada (PPP).

Aqui se encontra a base constitucional utilizada para fundamentar a possibilidade de indenização pelo Estado aos familiares de detentos falecidos no Complexo Penitenciário Anísio Jobim, ainda que esse seja administrado pela iniciativa privada.

\title{
4 Hipóteses de ReSPonsabilizaÇÃo do Estado e CAUSAS de EXCLUSÃO
}

De acordo com Hely Lopes Meirelles:

\begin{abstract}
...incide a responsabilidade civil objetiva quando a Administração Pública assume o compromisso de velar pela integridade física da pessoa e esta vem a sofrer um dano decorrente da omissão do agente público naquela vigilância. Assim, os alunos de rede oficial de ensino, pessoas internadas em hospitais públicos ou detentos, caso sofram algum dão quando estejam sob a guarda imediata do Poder Público, têm direito à indenização, salvo se ficar comprovada a ocorrência de alguma causa excludente daquela responsabilidade estatal (MEIRELLES, 2012, p. 731).
\end{abstract}

Excetuadas as raras hipóteses legais em que se aplica a teoria do risco integral, o direito pátrio admite causas de exclusão da responsabilidade estatal. Essas encontram lugar em situações onde não se consegue aferir o elemento subjetivo reprovável por parte do agente que exerce a função de órgão estatal.

Tais causas são normalmente enumeradas pela doutrina como: a) culpa exclusiva da vítima, b) culpa de terceiro, c) exercício regular de direito, d) caso fortuito ou força maior. 
No caso de culpa exclusiva da vítima, não há que se falar em responsabilidade do Estado. Porém, verificada a culpa concorrente entre o poder público e o administrado lesado, se deverá compartilhar o encargo, valendo-se do elemento subjetivo atinente à atuação estatal para mensurar o valor da indenização devida de cada um.

Se o dano for acarretado por conduta de terceiro, também não será possível atribuir qualquer responsabilidade ao Estado, desde que esse tenha observado seu dever de diligência. Exceção à regra ocorrerá quando lhe era exigível um dever de diligência especial destinado a evitar o resultado.

O exercício regular de direito, desempenhado pelo agente estatal dentro de seus limites funcionais e com observância do dever de diligência, também excluirá a responsabilização do ente estatal.

$\mathrm{O}$ caso fortuito ou de força maior afasta a responsabilidade civil em todos os setores do direito. Nesses casos, o dano será originário de situações que independem da vontade ou do controle do Estado, insuscetíveis de impedimento por esse.

Não obstante as duas figuras citadas sejam tratadas como sinônimo por alguns, existe na doutrina os que conceituam o caso fortuito como sendo o evento que não se pode prever e evitar. Os casos de força maior seriam atribuídos a fatos humanos ou naturais, que podem até ser previstos, mas de igual forma não podem ser impedidos.

Para a correta compreensão do evento ocorrido no presídio amazonense, dois pontos devem ser esclarecidos. $\mathrm{O}$ primeiro diz respeito à possibilidade de exclusão da responsabilidade do Estado; atribuindo os óbitos aos próprios detentos envolvidos na guerra de facções, impossível de ser controlada pelo estabelecimento prisional onde a chacina ocorreu.

Superada a afirmação citada e definida a responsabilidade estatal, passa-se à necessidade de comprovar a culpa do ente estatal, uma vez que o fato supostamente teve sua origem na má prestação do serviço de guarda dos presos e, portanto, deveria encaixar-se nos casos de "culpa anônima".

As duas questões foram tratadas pelo STF, no Recurso Extraordinário 841.526, interposto pelo Estado do Rio Grande do Sul contra 
acórdão do Tribunal de Justiça local (TJ-RS), que determinou o pagamento de indenização à família de um presidiário morto.

No caso em epígrafe, pairava dúvida a respeito da causa mortis do detento, divergindo as partes entre o homicídio e o suicídio.

Segundo a tese abraçada pelo governo estadual, de que o detento teria cometido suicídio, não seria possível atribuir ao Poder Público o dever absoluto de guarda da integridade física dos presos, especialmente quando não há qualquer histórico anterior de distúrbios comportamentais. Nessa hipótese, restaria comprometido o nexo de causalidade e, consectariamente, o dever estatal de indenizar.

Contudo, para a suprema corte, a causa da morte foi considerada irrelevante, sendo o Estado obrigado a indenizar a família do detento.

De acordo com o Ministro Luiz Fux, relator do mencionado recurso, ao adotar a teoria do risco administrativo, o direito brasileiro admitiu como possíveis causas excludentes do nexo de causalidade e exoneradoras de responsabilidade do ente público.

$\mathrm{O}$ ilustre Ministro ressalta diversas situações em que, dependendo das circunstâncias que a causaram, poderão ou não gerar o dever de indenizar ao Poder Público. Diversas seriam as consequências no caso de um preso suicida com histórico psiquiátrico indicativo dessa tendência e de outro que coloca fim à própria vida repentinamente, impulsionado por algum evento específico. Apenas na última hipótese não há que se falar em reparação aos familiares por omissão do Estado em virtude da total falta de previsibilidade do fato.

Pertinente aqui reproduzir trecho do didático voto exarado pelo referido relator:

...há casos em que a morte do detento simplesmente não pode ser evitada pelo Estado. Nesses casos, como já se ressaltou acima, rompe-se o nexo de causalidade entre o resultado morte e a omissão estatal no seu dever de manter a incolumidade física dos presos, o que afasta a responsabilização civil do ente público. Adota-se aqui, portanto, a teoria do risco administrativo, que permite a oposição de causas excludentes do nexo causal - as 
quais devem ser comprovadas pela Administração -, rejeitando-se, por consequência, a incidência da teoria do risco integral, não recepcionada pela ordem constitucional brasileira, que implicaria a imposição de responsabilidade civil ao Estado por toda e qualquer morte de detento (RE 841526/RS, STF).

Tal afirmação é plenamente aplicável às guerras entre facções dentro dos presídios. Destarte, faz-se necessário confirmar a observância, ou não, do dever específico de proteção ao detento, insculpido no artigo $5^{\circ}$., inciso XLIX, da Constituição Federal.

Sites de notícia afirmaram que o Complexo Penitenciário Anísio Jobim possuía estrutura para acautelar 454 pessoas, porém, na data da rebelião, contava com um total de 1.224 encarcerados, ou seja, 170\% maior ao que fora projetado. ${ }^{2}$

De acordo ainda com alguns veículos de imprensa, os agentes penitenciários foram negligentes ao colocar no mesmo ambiente presos de facções rivais.

Os argumentos citados, por si só, são capazes de fundamentar a possibilidade de reparação pelo Poder Público aos familiares de detentos mortos com base na violação do direito fundamental já mencionado.

No que diz respeito à necessidade de se comprovar a culpa do ente estatal em virtude do caráter omissivo do comportamento causador do dano, o referido magistrado alega que, não obstante paire controvérsia na doutrina e jurisprudência, a jurisprudência do STF vem se firmando no sentido de que nesses casos também seria adotada a teoria do risco administrativo. Dessa forma, não haveria necessidade de ser comprovar a culpa do Poder Público no evento em tela, bastando apenas que esse tivesse uma obrigação legal específica de agir para impedir o resultado.

A obrigação específica no caso do supracitado recurso extraordinário, assim como no evento do Complexo Penitenciário Anísio Jobim, é a manutenção da incolumidade física e moral do detento.

2 Fonte: http://g1.globo.com/am/amazonas/noticia/2017/01/presidio-que-teve-rebeliao-no-am-tem-170-de-presos-acima-da-capacidade.html. 
O já exposto nos leva à conclusão da obrigatoriedade de se indenizar os parentes dos presos vitimados na chacina do presídio amazonense. Contudo, paira ainda uma questão que constitui a grande celeuma deste trabalho: a concessão da administração do estabelecimento prisional à iniciativa privada, por meio do contrato de cogestão, seria capaz de elidir a responsabilidade do Estado? Ocorrendo a participação do poder público e de um ente privado num empreendimento, a quem caberá o dever de indenizar?

É sobre isso que passaremos a dissertar nos capítulos seguintes.

\section{Dos CONTRATOS PÚBLICOS COM ENTES PRIVAdOS PARA A AD- MINISTRAÇÃO PRISIONAL}

A participação privada em administração pública não é um conceito novo. Os serviços têm sido prestados por terceiros e as concessões têm sido delegadas a investidores privados por décadas. A novidade tem sido a associação entre o governo e o setor privado para a provisão de serviços usualmente prestados pelo setor público, por exemplo, as parcerias no setor prisional.

Hoje, no Brasil, existem duas modalidades de contratos públicos com entes privados para a administração prisional, cogestão e parceria público-privada. Os contratos de cogestão são regidos pela Lei 8.666/90, que institui normas para licitações e contratos da Administração Pública. Portanto, são contratos de até 60 meses, onde o privado cuida da gestão de alguns setores de uma unidade prisional que podem ser as áreas de saúde, jurídica, segurança e hotelaria. Difere-se dos contratos de cogestão a parceria público-privada, pois, além da gestão das áreas internas, o ente privado é responsável pela construção da unidade prisional. Outra diferenciação marcante é a duração do contrato de longo prazo, que pode chegar até a 35 anos. Atualmente, só existe um contrato de parceria público-privada prisional vigente no país. O Complexo Prisional em Parceria Público-Privada de Ribeirão das Neves em Minas Gerais opera com 2.160 vagas, não havendo superlotação, aliás, existe uma cláusula contratual impedindo que isto aconteça. 
As PPPs reúnem características da terceirização e da privatização, mas diferem delas porque envolvem contratos de longo prazo, construção e operação do empreendimento, e a cooperação entre o governo e o setor privado para implantar projetos e prover os serviços associados. A parceria público-privada (PPP) constitui uma opção nas situações nas quais a privatização ou a concessão comum não se aplica.

O que se busca com a parceria com o ente privado é agregar valor por meio do aumento da eficiência produtiva ou da técnica de produção e fornecimento do serviço. Para ser justificável, uma cogestão ou uma PPP tem que gerar uma combinação de eficiência produtiva e ganho social superior à provisão pública, considerando que o setor público está preparado para trocar alguma eficiência no ganho social por eficiência produtiva.

Com acerto Maria Sylvia Zanella de Pietro dispõe sobre as parcerias com a administração, como sendo:

...o contrato administrativo de concessão que tem por objeto a execução de serviço público, precedida ou não de obra pública, remunerada mediante tarifa paga pelo usuário e contraprestação pecuniária do poder público, ou a prestação de serviço de que a Administração pública seja usuária direta ou indireta, com ou sem a execução de obra e fornecimento e instalação de bens, mediante contraprestação do parceiro público (DI PIETRO, 2005 p. 161).

Verifica-se assim que a parceria público-privada possui natureza jurídica de contrato de concessão.

Sua origem encontra-se no período compreendido entre as décadas de 80 e 90, quando o Estado, descapitalizado por uma forte crise financeira, foi obrigado a recorrer ao capital privado com o fim de conseguir investimentos para incrementar sua infraestrutura. A aplicação do instituto ocorre notadamente em serviços públicos, nos quais para a iniciativa privada somente a cobrança de tarifas mostrava-se insuficiente para cobrir todos os custos da obra ou a legítima margem de lucro esperada pelo negócio. 
As parcerias público-privadas (PPPs) seguem basicamente o mesmo sistema das concessões clássicas. $\mathrm{O}$ capital privado é chamado a construir e explorar, durante certo tempo, um estabelecimento público, sendo este revertido ao final para o Estado. A diferença reside no fato de que, não sendo o serviço público pago por seus usuários, a amortização e remuneração do investidor será assegurada pelo próprio Poder Público por meio de pagamentos regulares feitos durante o período de vigência do contrato.

No direito brasileiro, as PPPs foram regulamentadas pela Lei 11.079/04, que em seu bojo disciplina suas duas modalidades, a citar: administrativa ou patrocinada.

A diferença entre essas reside na maneira de remuneração do parceiro privado. Na concessão administrativa, os serviços serão fruídos diretamente pelos particulares, por meio de tarifas, mas com a adição de contraprestação pecuniária provida pelo próprio Poder Público. Já na concessão patrocinada, o próprio Poder Público goza de forma direta ou indireta do serviço prestado, arcando com sua remuneração a título de contraprestação.

Ambas se diferenciam das concessões tradicionais, regidas pela Lei 8.987/95, que regulam a transferência de serviços ou obras públicas quando não envolver contraprestação pecuniária do parceiro público ao parceiro privado.

Como pontos comuns às duas modalidades. pode-se enumerar: a) a contraprestação do poder público ao parceiro privado, que não existe na concessão tradicional; b) a repartição de riscos, inclusive os referentes a caso fortuito, força maior, fato do príncipe e teoria da imprevisão; c) o compartilhamento com a Administração Pública dos ganhos do parceiro privado, decorrentes da redução do risco de crédito dos financiamentos utilizados pelo parceiro privado; d) as garantias prestadas pelo poder público ao parceiro privado e ao financiador do projeto; e) a obrigatoriedade de constituição de sociedade de propósitos específicos; f) possibilidade de aplicação de penalidades pelo parceiro privado ao parceiro público (que só é aceitável quando se tratar de multa ressarcitória, já que o particular não pode aplicar pena ao poder público, que é 
o titular único do poder sancionário; g) a limitação de prazo de duração do contrato, que não pode ser inferior a 5 anos, nem superior a 35 anos, incluindo eventual prorrogação; h) a exigência de observância da Lei de Responsabilidade Fiscal; i) algumas normas específicas quanto ao procedimento da licitação, que derrogam parcialmente as Leis 8.666/93 e a $8.987 / 95$.

É necessário ressaltar que, no caso das PPPs, existe expressa previsão legal a respeito da repartição do risco entre as partes contratantes, conforme se verá adiante. Contudo, no caso do Complexo Penitenciário Anísio Jobim (Compaj), a modalidade de parceria utilizada pela Administração Pública foi de cogestão, a qual é regulada pela Lei 8.666/93 e merecerá considerações também no capítulo seguinte.

\section{AplicaÇão da legislaÇão Vigente aO CASO PRÁtico}

Observa-se assim que a cogestão e a parceria público-privada com a administração possuem como características a repartição dos riscos entre os contratantes, mesmo em eventos originados por caso fortuito, de força maior, fato príncipe ou da álea extraordinária do negócio.

Tal possibilidade foi trazida pela Lei $11.079 / 04$ em seu artigo $4^{\circ}$., o qual se transcreve a seguir, teve como objetivo atrair o investidor particular, uma vez que nas concessões comuns os riscos eram prioritariamente do concessionário privado.

Artigo $4^{\circ} \mathrm{Na}$ contratação de parceria público-privada serão observadas as seguintes diretrizes: (...)

$\mathrm{VI}$ - repartição objetiva de riscos entre as partes (BRASIL, 2004).

Dessa forma, depreende-se que, em virtude do risco assumido pelo setor privado ao celebrar o contrato com o poder público, cabe àquele arcar com parte dos custos de eventuais danos que seu serviço venha a causar a terceiros. Tal constatação torna-se óbvia, principalmente pelo caráter oneroso da contratação, ou seja, a prestação do poder conce- 
dente, traduzida na remuneração feita ao concessionário, corresponderá a uma contraprestação deste, cuja inexecução ou execução deficiente deve acarretar consequências.

O mesmo argumento é perfeitamente aplicável para os casos de cogestão. Ademais, a Lei 8.666/93, ao tratar da repartição de responsabilidade, dispõe que:

Artigo 70. O contratado é responsável pelos danos causados diretamente à Administração ou a terceiros, decorrentes de sua culpa ou dolo na execução do contrato, não excluindo ou reduzindo essa responsabilidade a fiscalização ou o acompanhamento pelo órgão interessado (BRASIL, 1993).

No caso em tela, a contraprestação devida pelo parceiro privado era o correto acautelamento dos detentos, atividade típica de Estado e, portanto, impossível de ser delegada por esse na sua integralidade.

Assim, no caso específico do Compaj, a gestão era feita de forma compartilhada, sendo o cargo de diretor ocupado por funcionário público.

Porém, diversas atividades de controle interno e externo eram realizadas pela concessionária, como a revista de presos e de visitas que tinham o objetivo de evitar a entrada de qualquer material potencialmente ofensivo no local. A falha na prestação desse serviço indubitavelmente foi uma das causas para as mortes ocorridas na chacina de $1^{\circ}$. de janeiro.

Acrescente-se ainda que, ao aceitar maior número de presos do que suas instalações permitem, a empresa tacitamente assume a obrigação de zelar por todos ou assumir o risco advindo da superlotação.

Ainda que se adote a tese de que não cabe ao Estado eximir-se da responsabilidade em virtude do dever de fiscalização sobre a atividade delegada, o que encontra óbice legal no caso da cogestão, caberia à concessionária ao menos arcar de forma objetiva e solidária com os danos causados pela má prestação do serviço de acordo com o mencionado novel.

Insta fazer outra comparação entre as modalidades de cogestão e de parceria público-privada no que tange à divisão de responsabilidades. 
É no corpo do contrato que a repartição de responsabilidade entre o poder público e o setor privado será delimitada, conforme depreendese da leitura do artigo 55, inciso VII da Lei 8.666/93:

Artigo 55. São cláusulas necessárias em todo contrato as que estabeleçam:

(...)

VII - os direitos e as responsabilidades das partes, as penalidades cabíveis e os valores das multas (BRASIL, 1993).

No mesmo sentido, de maneira mais abrangente, esclarece o artigo $5^{\circ}$. da Lei 11.079/04:

Artigo 5․ As cláusulas dos contratos de parceria público-privada atenderão ao disposto no art. 23 da Lei $\underline{\text { no }}$ 8.987, de 13 de fevereiro de 1995 , no que couber, devendo também prever: (...)

III - a repartição de riscos entre as partes, inclusive os referentes a caso fortuito, força maior, fato do príncipe e álea econômica extraordinária (BRASIL, 2004).

Com base no exposto, é possível perceber a importância do pactuado entre as partes em ambas as modalidades de parceria com o Poder Público.

Destarte, faz-se necessária a leitura do contrato de concessão celebrado entre o Estado do Amazonas e a empresa administradora, UMANIZZARE GESTÃO PRISIONAL E SERVIÇOS LTDA., para compreensão da mencionada divisão de responsabilidade entre ambas.

A cláusula terceira do Termo do Contrato de Prestação de Serviços de Gestão Prisional n ${ }^{\circ}$. 018/2014-SEJUS, ao enumerar as obrigações da contratada, assim dispõe:

A CONTRATADA é obrigada a adotar todas as medidas preventivas necessárias para evitar danos a terceiros em consequência da execução dos trabalhos, além das obrigações abaixo discriminadas: (...) 
III. Manter os postos de trabalho nos horários determinados pelo CONTRATANTE assumindo a responsabilidade por eventuais prejuízos e/ou danos decorrentes do mau funcionamento; (...)

E prossegue na cláusula quarta:

A CONTRATADA é única, integral e exclusiva responsável, em qualquer caso, por todos os danos e prejuízos, de qualquer natureza, causados direta ou indiretamente ao CONTRATANTE ou a terceiros, decorrentes de sua culpa ou dolo na execução dos serviços, objeto deste contrato e quaisquer que tenham sido as medidas preventivas adotadas, respondendo por e seus sucessores, não reduzindo ou excluindo essa responsabilidade a fiscalização ou acompanhamento pelo CONTRATANTE.

Constata-se dessa forma que a atribuição de toda e qualquer responsabilidade por danos advindos do serviço deverá ser direcionada à concessionária. Assim, com base na força normativa dos contratos, forçosamente conclui-se que a empresa UMANIZZARE GESTÃO PRISIONAL E SERVIÇOS LTDA. deveria, em tese, ser a primeira demandada no caso de eventual indenização aos familiares de presos mortos.

Não é por outro motivo que várias empresas privadas, ao celebrar contratos com a administração pública, realizam também contrato de seguro para resguardar suas atividades.

Como exemplo, cita-se o Complexo Penitenciário Público-Privado de Ribeirão da Neves em Minas Gerais, administrado pela GPA (Gestores Prisionais Associados S/A), onde o contrato de gestão estipula em seu bojo a possibilidade de realização de seguros. ${ }^{3}$

Fonte:http://www.ppp.mg.gov.br/images/documentos/Projetos/concluidos/ Complexo_Penal/contrato/Contrato\%20PPP\%20Complexo $\% 20$ Penal $\% 20$ 330639.54.1338.09.pdf 
A ATRIBUIÇÃO DE RESPONSABILIDADE CIVIL AO ESTADO EM ESTABELECIMENTOS PRISIONAIS GERIDOS ATRAVÉS DE COGESTÃO E PARCERIAS PÚBLICO-PRIVADAS: UM ESTUDO APLICADO AO PARADIGMÁTICO EVENTO

\section{Considerações Finais}

O objetivo do presente trabalho foi traçar as linhas gerais da responsabilidade civil extracontratual do Estado no ordenamento brasileiro, notadamente no que diz respeito à modalidade de contratos entre a iniciativa privada e a administração pública.

Para tanto, iniciou-se a pesquisa através do estudo sobre a evolução da responsabilidade no direito comparado e posteriormente no ordenamento pátrio. Desse modo, foi possível constatar que, como regra, o Brasil adota a teoria da responsabilidade objetiva como forma de disciplinar as suas relações com os administrados, admitindo em certas situações causas excludentes do nexo de causalidade. Tal entendimento, encontra assento na legislação interna e jurisprudência da suprema corte.

Após breve exposição a respeito do tema, passou-se a discorrer sobre os contratos de concessão celebrados nos termos da Lei 8.666/90 e Lei de Parceria Público-Privada. Na última modalidade contratual foi possível perceber que, como forma de incentivar a participação do particular nos empreendimentos do Estado, estabeleceu-se a possibilidade de repartição da responsabilidade por danos advindos na execução do serviço concedido.

Contudo, tal divisão deverá ser prevista no contrato de concessão, sendo que, em caso de omissão do poder concedente, caberá a aplicação subsidiária da lei 8.987/95 que no seu artigo 25 atribui a responsabilidade por eventuais danos causados a terceiro ao concessionário.

Artigo 25. Incumbe à concessionária a execução do serviço concedido, cabendo-lhe responder por todos os prejuízos causados ao poder concedente, aos usuários ou a terceiros, sem que a fiscalização exercida pelo órgão competente exclua ou atenue essa responsabilidade (BRASIL, 1995).

A norma citada reproduz a regra contida no artigo 70 da Lei 8.666/93 que gere os contratos de cogestão. Dessa forma, as duas mo- 
dalidades, do ponto de vista legal, estão em perfeita consonância no que tange à atribuição de responsabilidade por atos lesivos.

O estudo valeu-se do recente evento ocorrido no Complexo Penitenciário Anísio Jobim para ilustrar a aplicação do instituto da responsabilização estatal quando envolvido o particular na prestação do serviço.

Foi proposta a análise do caso concreto para, ao final, concluir-se pela pertinência ou não da decisão do Estado do Amazonas em assumir a responsabilidade pela indenização aos parentes dos presos mortos na chacina.

Imediatamente após o termino do incidente, o Estado do Amazonas determinou o início dos trâmites para a indenização aos familiares das vítimas. A mencionada decisão foi ancorada na Constituição Federal e jurisprudência dos tribunais superiores já estudadas neste artigo.

$\mathrm{O}$ anúncio, ao que parece, foi motivado pela grande repercussão do caso que demandava uma rápida resposta do governo. Contudo, o já exposto permite adotar raciocínio diverso da referida decisão que, ao que parece, não foi a mais acertada.

Ora, observando o contrato celebrado entre o Estado e a empresa Umanizzare, não resta dúvida que a última deveria arcar com tais indenizações. Tal conclusão pode ser embasada tanto juridicamente quanto faticamente, uma vez que foi demonstrada a falha na prestação do serviço contratado.

Ao assumir o ônus de ressarcir os parentes das vítimas por suas perdas, sem sequer questionar a responsabilidade da contratada, o Estado do Amazonas de forma imprudente lesou o erário; poupando aquela que, por aferir lucro com sua atividade, deveria, como em qualquer relação empresária, suportar os custos dessa.

Não obstante o aparente equívoco da decisão, nada impede que, após realizar o pagamento aos requerentes, o poder público ingresse com a devida ação de regresso em desfavor da empresa concessionária, pleiteando assim o ressarcimento de tais valores. Ainda não foi emitida qualquer nota demonstrando tal intenção pelo Estado.

Por fim, é necessário ressaltar que o presente artigo objetivou discutir a designação de responsabilidade pelas mortes ocorridas no presídio e não seu cabimento que encontra fundamento na própria ordem 
constitucional, cujo respeito à integridade física e moral ao preso está expresso no artigo $5^{\circ}$., inciso XLIX. ${ }^{4}$

Ao opinar em casos similares ao aqui tratado, deve o exegeta ter em mente o tipo de sociedade que se deseja construir. Aquela que, inobstante a pouca chance de recuperação, investe no cidadão buscando sua reabilitação e reinserção no meio social por meio de uma pena cumprida com dignidade; ou aquela que, sem muitas vezes oferecer aos infortunados acesso ao mínimo existencial, lhes vira as costas ante o menor deslize, trancafiando-os em "masmorras", cuja falta de estrutura e cuidado inviabilizará qualquer chance de um retorno saudável à comunidade.

Negar a possibilidade de responsabilização do ente estatal, ou quem lhe faça as vezes, é afirmar por vias transversas que as condições degradantes impostas atualmente aos encarcerados no Brasil são normais ou, pior ainda, devidas a esses como parte da punição.

\section{REFERÊNCIAS}

BANDEIRA DE MELLO, Celso Antônio. 32a . ed. Curso de Direito Administrativo. São Paulo: Malheiros Editores, 2015.

BRASIL. Constituição (1988). Constituição da República Federativa do Brasil. Brasília, DF: Senado, 1988.

BRASIL. Código Civil, Lei no 10.406 de janeiro de 2002. Institui o novo Código Civil brasileiro. Brasília, DF: Congresso Nacional, 2002.

4 Contrapondo aos que defendem o não cabimento de indenização em virtude dos antecedentes e da personalidade dos detentos vitimados, reproduz-se trecho do voto proferido pelo Excelsior Ministro Luís Roberto Barroso, no qual se discutia a possibilidade de indenizar detentos submetidos à situação degradante por meio diverso do pecuniário: "O Estado tem o dever de indenizar os danos morais causados pelo encarceramento em condições atentatórias aos mínimos padrões de dignidade. Não se pode invocar a teoria da reserva do possível ou outros subterfúgios teóricos para afastar a responsabilidade civil do Estado na hipótese. Isso implicaria negar a uma minoria estigmatizada a titularidade de seus direitos mais elementares à integridade física e moral, à não submissão a tratamento desumano ou degradante e a penas cruéis, em frontal violação à Constituição. Seria, portanto, legitimar uma concepção desigualitária a respeito da dignidade humana, que nega aos presos o seu valor intrínseco, como se não se tratasse de seres humanos” (RE 580252/MS, STF). 
BRASIL. Lei no ${ }^{\mathbf{~}} \mathbf{8 . 6 6 6}$, de 21 de junho de 1993. Regulamenta o art. 37, inciso XXI, da Constituição Federal, institui normas para licitações e contratos da Administração Pública e dá outras providências. Brasília, DF, 1993. Disponível em: <http://senado.gov.br>. Acesso em: 20 fev. 2017.

BRASIL. Lei $\mathbf{n}^{\mathbf{0}} \mathbf{. 8 . 9 8 7}$, de 13 de fevereiro de1995. Dispõe sobre o regime de concessão e permissão da prestação de serviços públicos previsto no art. 175 da Constituição Federal, e dá outras providências. Brasília, DF, 1995. Disponível em: <http://senado.gov.br>. Acesso em: 20 fev. 2017.

BRASIL. Lei $\mathbf{n}^{\mathbf{0}}$. 11.079, de 30 de dezembro de 2004. Institui normas gerais para licitação e contratação de parceria público-privada no âmbito da administração pública. Brasília, DF, 2004. Disponível em: <http://senado.gov.br>. Acesso em: 21 fev. 2017.

BRASIL. Supremo Tribunal Federal. Recurso Extraordinário no . 8.41526RS, Relator: Min. Luíz Fux. Brasília. Diário da Justiça da União, 1º ago. 2016.

BRASIL. Supremo Tribunal Federal. Recurso Extraordinário $\mathbf{n}^{\circ}$. 580252MS, Relator: Min. Teori Zavascki. Brasília. Diário da Justiça da União, 24 fev. 2017.

DINIZ, Maria Helena. Curso de Direito Civil Brasileiro - Responsabilidade Civil, 21. ed. São Paulo: Saraiva, 2007.

DI PIETRO, Maria Sylvia Zanella. Parcerias na administração pública: concessão, permissão, franquia, terceirização, parceria público-privada e outras formas, 5. ed. São Paulo, 2005 p. 161.

FILHO, José dos Santos Carvalho. Manual de Direito Administrativo, 29. ed. São Paulo: Atlas, 2015.

FILHO, Marçal Justen. Curso de Direito Administrativo, 8. ed. Belo horizonte: Fórum, 2012.

http://g1.globo.com/am/amazonas/noticia/2017/01/presidio-que-teve-rebeliao-no-am-tem-170-de-presos-acima-da-capacidade.html

https://noticias.uol.com.br/cotidiano/ultimas-noticias/2017/01/09/uol-confere-gestao-privada-de-presidio-nao-tira-responsabilidade-do-governo-do-am. $\underline{\mathrm{htm}}$

http://www.ppp.mg.gov.br/images/documentos/Projetos/concluidos/Com- 
A ATRIBUIÇÃo DE RESPONSABILIDADE CIVIL AO ESTADO EM ESTABELECIMENTOS PRISIONAIS GERIDOS ATRAVÉS DE COGESTÃO E PARCERIAS PÚBLICO-PRIVADAS: UM ESTUDO APLICADO AO PARADIGMÁTICO EVENTO OCORRIDO NO COMPLEXO PENITENCIÁRIO ANÍSIO JOBIM

plexo_Penal/contrato/Contrato\%20PPP\%20Complexo\%20Penal $\% 20$ 330639.54.1338.09.pdf

http://www.seap.am.gov.br/wp-content/uploads/2016/06/CT-N\%C2\%BA-018-2014.pdf

MARINELA, Fernanda. Direito Administrativo, 10. ed. São Paulo: Saraiva, 2016.

MEIRELLES, Hely Lopes. Direito Administrativo Brasileiro, 39. ed. São Paulo: Malheiros Editores, 2013.

PIETRO, Maria Sylvia Zanella Di. Direito Administrativo, 23. ed. São Paulo: Atlas, 2010.

\section{SOBRE OS AUTORES}

Marco Antonio Rocha Ferreira

Bacharel em Direito (Faculdade de Direito Milton Campos). Delegado de Polícia Civil em Minas Gerais. Professor na ACADEPOL nas Matérias de Direitos Humanos e Criminologia.

CV: http://lattes.cnpq.br/5599267265433088

E-mail: marcoantoniorferreira@hotmail.com.

\section{Hamilton da Costa Mitre de Andrade}

Bacharel e Mestre em Direito (Faculdade Dom Helder Câmara). Advogado. Professor de Direito Penal da Pontifícia Universidade Católica. CV: http://lattes.cnpq.br/4285744525417864

E-mail: hamilton.mitre@hotmail.com.

Submetido em:23-8-2017

Aceito em:1-12-2017 